\title{
A Study on the Correlation of True Love and Christianity through the Examination of the Inter-Textuality of the Bible and Toni Morrison's Song of Solomon
}

\author{
$\operatorname{Mia~Kim}^{1}$ \\ ${ }^{1}$ Professor, Liberal Arts Department, Jeonju University, Korea, kmia14@nate.com
}

\begin{abstract}
Toni Morrison grew up in a Christian family where she naturally accepted the value of Chritianity. Growing up as a writer, she witnesses the devastating and unequal lives of black people. She tried hard to embrace the similarity of the adversity of Jesus and blacks in her novels, and its fruit wasthe Song of Solomon. This paper is aimed to examine the power of true love and its influence on the basis of the inter-textuality of the Bible and Toni Morrison's third novel, Song of Solomon. A similar study on the intertextuality of Morrison's novels and the Bible was ever proceeded by Whener earlier. However, Whener was more focused on a formal approach of the two texts. Therefore, it must be a meaningful work to approach the content examination of the correlation of the Bible and Song of Solomon. This study questioned and pursued the power of true love based on Christianity embraced in the two texts.It compared and analyzed the growing-up story of Milkman, who went through a most conflicting life and huge changes, awakening the true lovein life. This study also examined the essence of true love through the analysis of Jesus Christ's life in some chapters of the Bible. In a methodological aspect, the whole process of this research was proceeded on the grounds of Therese Higgins's perspective. This research reached a conclusion that the true meaning of love in Song of Solomon embraced the same characteristic and connonality of love as the Bible, and both of them are quite correlated.
\end{abstract}

Keywords: Love, Flight, Correlation, Intertextuality, Song of Solomon, Bible

\section{Introduction}

Christianity and love are very common topics which appear in Toni Morrison's novels. Morrison saysthe Bible is not a part of reading history, but a part of real life. Morrison tells how her family members grew up in the boundaries of Christianity through this episode. For example, Morrison's grandmother's name, Flak (Rah mah) was given to her by her grand mother's father who chose that name in Bible with her eyes covered. Morrison's family members talk and share Jesus Christ's life, and they think they can always adapt the Bible to black people's situation. As black spirituals are sung in black people's daily lives, the Bible is at the center of Morrison's life. Therefore it is natural that the spirit of Christianity and the Bible is melted into her novels.

In early novels, Morrison accepted and simultaneously criticized parts of Christianity through the characters. In her fist novel, The Bluest Eyes (1970), Peacola prays for God to let her have blue eyes like whites on a daily basis. Another character in the novel, Dosphead Church shows the resistant attitude against God, who thinks God creates evil in the world. In her second novel, Sula (1973), Morrison shows double-sided aspects on Christianity through the comparison of Nel and Sula. Nel disguises herself with

Received: July 26, 2021; $1^{\text {st }}$ Review Result: September 14, 2021; $2^{\text {nd }}$ Review Result: October 28, 2021 Accepted: November 30, 2021 
Christian mercy and order, and Sula develops herself with resistant ideology against the stereotyped norm of society.

Morrison's third novel shows more direct relation with Christianity,Song of Solomon (1977). As the title of this novel suggests, Song of Solomon contains quotes from the Bible. The characters of this novel are named after the historic figures of the Bible. Song of Solomon has the same conversational structure in the aspect of its theme as Song of Songs in the Bible. Song of Solomon mainly focuses on the matter of Milkman's self-growth, the myth of an African's flying, the meaning of 'flying' in the category of the structural analysis of African American's traditional myth, still existing colonial tracesafter the liberation of slavery, and the women's life oppressed by patriarchal male power.

The paper, "the rebirth of Milkman in Song of Solomon" mentioned that Milkman gives up 'the Bible' which is the symbol of Western individuality and Western culture to live the life with a strong will[1]. Milkman is reborn with an identity of challenging the existing recognition of race and sex by resisting the Bible and its meaning. Meanwhile, Beth Benedrix pays attention to the comparison of Song of Solomon and Song of Songs and Romans of the Bible in the paper, "Fundamental fatality: 'Song of Solomon' and a journey home". Benedrix[2] analyzes the tension of human being's fear of being abandoned or being too close in the context of the Bible. He also indicates that Morrison rewrites Ruth through Milkman's mother, Ruth Foster Dead. These papers mentioned above pinpoint that Morrison shows a resistant attitude against the Bible and quotes biblical factors to reveal the limit of the Bible.

This paper aimed to look into the correlation of true love and Christianity in the two texts, the Bible andSong of Solomonbased on Therese Higgins's perspective. Higgins asserted that there is a clear correlation in the power of true love and Christianity embraced in the Bible and Toni Morrison's third novel, Song of Solomon. In the process of developing the idea of re-enlightening the intertextuality of these two texts, this study will methodologically examine the interrelated elements of the power of true love and Christianity through the analysis of the characters of Song of Solomon and the words of the Bible. This research starts with Higgins's argument and examine if his argument is convincing. To this end, this study will compare and analyze the true meaning of love through the inter-textuality of the two texts.

This study is deemed important to address the confusion of African Americans in knowing their own identity and be aware of the true meaning of love and its power. The most cosmopolitan and greatest love on human kind is Jesus's love recorded in the Bible. This research is intended to play a role in awakening modern people living trapped in their own world and suggest another phase for the study of the correlation of the Bible and literature.

\section{The Examination of the Meaning of True Love based on the Two Texts, Song of Solomon and the Bible}

This chapter will look into the connection between the vision of redemption based on the comparison and analysis of the Bible and Song of Solomon. It will analyze Morrison's philosophy of love through the comparison and examination of them. She tried to deal with the implicative meaning of love as generosity and acceptance in her novel. Blacks are eager to have a breakthrough to deal with their anger and pain from oppressive labor. Blacks' anger against whites is very oppressing and destroying, and they need a means to get it over. The verses from 10 to 12 in the chapter 4 in Daniel of the Bible includes Black's dream world through Christianity.

These are visions I saw while living in my bed: I looked, and there before me stood a tree in the middle of the land. Its height was enormous. The tree grew large and strong and its top touched the sky; it was visible to the ends of the earth. Its leaves were beautiful, its fruit abundant, and on it was food for all. Under it the bveasts of the field found shelter, and the birds of the air lived in the branches; from it 
every creature was fed[3].

The basic principle of Christianity to love even foes sublimates blacks' anger to another level of love by accepting whites, and it is the only way to drive up the state of blacks' spirituality. In the New Testament, Jesus Christ is weak and innocent having the similarity of blacks heartrending life. It evokes their sympathy for Christianity. The sacrifice of innocent Jesus's death does not end with his death, but it is connected to his redemption. It means for blacks to have hope of glory, freedom and victory in the future, and it has a huge influence on African American's literature[4].

The starting point of Song of Solomon and the Bible is derived from self-love. According to Stephanie $\mathrm{Li}$, Morrison says that a person who loves himself and has a firm identity can love other people truly and have sincere sympathy for others[5]. Higgins mentions that they have to be the subjects of love to love others truly[6]. This statement means that each individual has to decide the aspect of love, and only the ones having their own identity can accomplish perfect love.

Self-love is the ground of all human relationships. A theologian, Jonathan Edwards mentions that "we must love ourselves next to the love we can give to God[7]." The phrase, "Love neighbors as yourself" (Matthew 22:39) shows that self-love is the foundation to love others. Jesus says the brotherly union with neighbors, not telling us the order or the degree of love for brothers or neighbors. This is the new commandment of Jesus to "love each other[8]." It shows that self-love and love of others are not separated, and it is basically one concept. This love does not require the order or the limit of 'loving self first and others'. It means a perfect identification with neighbors, and self-love and love of others are formed at the same time through becoming one, not as separated concepts.

Song of Solomon shows the characters who fail in love due to the lack of positive self-love. Milkman and Hagar are the ones having excessive love of themselves. Milkman and Hagar grow up in the circumstances of having economic differences. However, they have a common point that both of them are self-centered and they grow up in families supporting their desire. Milkman, the only son in a black middle class family, grows up with the care and sacrifice of his sisters as well as the support of Macaon Dead and Ruth. Although Hagar is born in the lowest class of the black community, Pilot provides all the things to fill Hagar's desire. The love of Milkman and Hagar ends up with being merciless and cold. Their love is filled with empty self only focusing on self-desire, not full-filling each other's respect and generosity.

Hagar becomes destroyed losing her self-identity, without fear, without desire, and without her name while in love. She thinks Milkman is a house in the world to keep her safe. Milkman's letter telling Hagar to say goodbye and his disappearance from her life makes her lose subjectivity. From then on, Hagar wanders looking for Milkman. Hargar's struggle to take back Milkman means recovering her identity. However, Hagar comes to face Milkman's cold shoulder and her ego is on the verge of collapse. The love that is lost by others is not the right love.

Like Milkman's friend, Guitar mentions, love acknowledges the difference of each other and guarantees each other's independence and subjectivity like "the clouds surrounding a mountain". Hagar, neglecting the exploration of herself and accepting the others instead of herself, comes to fail to love herself as well as others. Milkman's attitude has an excessive adherence to himself, but it isolates him from all the people around him by only having superficial relationships. The isolation from others causes Milkman to have a sense of inferiority about himself. Milkman, feeling himself inferior to his father, thinks his legs are uneven. These thought of uneven legs shows the negativity on his self-ego. Ever since his journey to the Southern area, he feels his legs are becoming even while discovering the roots of his ancestor's life and history. Milkman finally recognizes his legs are completely balanced after hunting in Shalima. It means Milkman finally gains sympathy with the love of his family, especially Pilot's and Hagar's love for him. Milkman's attitude symbolizes black's lack of self-esteem derived from their scars and trauma from white's domination. Milkman's wandering and thorough isolation from others lets 
himself prepare for the change and development like the period that Jesus needed for true communication with others[9].

The narrative strategy of the text of Song of Solomon indicates that the only mutually balanced love is positive. The first word of this novel is 'North Carolina life insurance'. This life insurance company is the first one for blacks. The word of 'mutual life' suggests that people's lives are not only for oneself but for each other. Especially the word of 'mutual' lets its meaning extend to the category between black man and woman, the classes, the couples, and the rich and the poor. The key of 'mutual love' is to keep the balance and harmony certifying the meaning of existence by properly reacting 'calling and response' for each other, not just filling physical desires.

Morrison shows the importance of mutual love through different types of love in this novel. The scene of Luth and Maycon's passionate love in the early marriage life can easily be forgotten because of their current indifference to each other. Maycon tries to accept Luth's requirement around that time, but the doubt of Luth's father makes the couple distant. With the effect of a mythical herb Pilot saved, the couple can conceive Milkman. Other than that, Luth and Maycon have no love for each other. Milkman and Hagar also have met for ten years, but they don't understand each other in depth.

Song of Songs of the Bible shows the repetitive pattern of balanced and unbalanced love, and tells the significance of mutual love. In chapter 5 of Song of Songs, there is a woman who decorates herself like Hagar. Saechan translates this scene into that which the woman is absorbed in herself more than God wants her to be[10]. In Song of Solomon, Luth wants her husband to treat her well like her father did. Luth's sacrifice and her unhappy life can defend her, but her way of love is not the one to respect the other. The reason Maycon got married to Luth is to accomplish goals of wealth and fame, and their relationship is ignited from selfish idea of filling each's desire. Milkman wants Hagar to follow his requirements, and Hagar also wants Milkman to follow her requirements. The image of the woman adhering to the myrrh and her devastation in Song of Songs is very similar to Hagar who sticks to clothes and cosmetics. The woman, in the verses from 1 to 6 in the chapter 5 in Song of Songs of the Bible, lose the balance of her life due to the loss of love shows quite similar images of Hagar.

I have come into my garden, my sister, my bride; I have gathered my myrrh with my spice, I have eaten my honeycomb and my honey; I have drunk my wine and my milk. Eat, $\mathrm{O}$ friends, and drink; drink your fill, O lovers. I slept but my heart was awake. Listen! My lover is knocking: "Open to me, my sister, my darling, my dove, my flawless one. My head is drenched with dew, my hair with the dampness of the night." I have taken off my robe- must I put it on again? I have washed my feet- must I soil them again? My lover thrust his hand through the latch-opening; my heart began to pound for him. I arose to open for my lover, and my hadns dripped with myrrh, my fingers with flowing myrrh, on the handles of the lock. I opend for my lover, but my lover had left; he was gone. My heart sank at his departure. I looked for him but did not find him. I called him but he did not answer[11].

As she wanders to find her loved one but does not find him, Hagar tries hard to look for Milkman. Hagar's wandering ends up with her witnessing Milkman being with another woman. The loss of the mutual love between Milkman and Hagar eventually causes Hagar's death.

Morrison suggests the example of balanced love through the relationship between Milkman and Sweet in the village of Shalima after Milkman completed self-development. As Joyce Middleton indicates, Morrison delineates their balanced love by crossing subject into Milkman and Sweet one sentence at a time in this scene[12]. The image of Milkman and Sweet is connected to the ones in the verses from 4 to 10 in the chapter 8 in Song of Songs of the Bible who are so happy with their balanced love.

Daughters of Jerusalem, I charge you: Do not arouse or awaken love until it so desires. Who is this coming up from the desert leaning on her lover? Under the apple tree I roused you; there she who was 
in labor gave you birth. Place me like a seal over your heart, for love is as strong as death, its jealousy unyielding as the grave. It burns like blazing fire, like a mighty flame. Many waters connot quench love; rivers cannot wah it away. If one were to give all the wealth of his house for love, it would be utterly scorned. We have a young sister, and her breats are not yet grown. What shall we do for our sister for the day she is spoken for? If she is a door, we will enclose her with panels of cedar. I am a wall, and my breats are like towers. Thus I have become in his eyes like one bringing contentment[13].

A theologian, Taylor pinpoints that the two people become complete one in the last scene of Song of Songs, and the bride is not absorbed in any other personal relationship[14]. It is not a volatile love. It is a love which does not make them feel fussy and unstable, because it never perishes depending on each's need. Their love harmoniously responds and calls, and they never feel poor.

\section{TheExamination of the Correlation of true love and Christianity in Song of Solomon and the Bible}

Morrison does not think one sided love is positive. In her novels including diverse aspects of love, Morrison emphasizes that love should be mutual[15]. Unlike the love of Luth and Maycon, and Hagar and Milkman, the relationship of Sweet and Milkman shows the love filling each other's desire and needs through sharing and respect. Therefore their love lets each other be free, and at the same time, become one.

For Morrison, love is the means for healing.African American's existential value has been destroyed on purpose in American society. White people give countless hurt to black people, and it is left unattended. In the context of suppression, Morrison places an emphasis on the matter of 'choice' for African American characters[16]. Song of Solomon suggests black's way of responding to whites' suppression and discrimination, and it says that they have to start from their inner-self.

Firstly, Maycon Dead is a character belonging in this category. For him, it is a way to have an equal position with whites by possessing money and status. Maycon has a mental scar of white's tyranny taking away his father and their farm in his childhood. Maycon justifies his desire for possession insisting that black people can enjoy the rest of their lives at a beautiful beach someday which used to be one only for whites. To increase his possessions, Maycon does not care about how to treat poor people like Guitar's family and kicks them out to the street. The way of Maycon's increasing property is the same as the way of white's handling over slaves. Alexander JC and Eyeman Rm agree on Macon's attitude that he imitates white master's ideology on the concept of indiscriminate possession[17]. A good boy who used to help his father's farming grows up to be the same man as a white master. Macon treats the family members and the tenants as his belongings just like the whites did. He tries to heal his past scar with the same social status and the accumulation of wealth as whites. With the accumulation of some degree of wealth, Macon locks himself in the sate of mental slave arming with white's ideology. He is afraid that other people might recognize poor and raggedy Pilot as his sister. It shows that Macon's identity and his life gets more and more barren[18].

Secondly, Guitar is the person who responds to white's violence with black's violence. He never forgets white's attitude of killing his father with saw and shows some kind of love. Even after becoming a grown up person, Guitar is obsessed with sweet things reminding him of his childhood. He is selected as a member of the secret organization Seven Days. It is the organization confronting against white's violence with the same violence as the Ku Klux Klan. There is an error in Guitar's choice of it. This group shows double aspects of political adaptation on leading blacks inside the black community professing its difference from white's. Seven Days insists that they work for blacks, but they virtually work for exclusive love among blacks. It shows a closed aspect that they accept only the blacks who have the same political perspective. One of the examples reflecting Guitar's point of view is that he 
regards Milkman's family as 'whites' and pushes them out of his boundary.

Guitar and Seven Days lead themselves to destruction with endless anger. Milkman has doubt as to why Guitar wants to be like whites by becoming a member of Seven Days. As a member of Seven Days, Guitar always emphasizes their cause killing only whites, not blacks, but he finally comes to kill Pilot with an attempt to kill Milkman. They eventually end up making self-destructive moves with uncontrollable anger against whites, and it causes Guitar to try to kill Milkman[19].

Guitar's violent attitude is the result of passively internalizing white's perspective seeing blacks. Guitar changes himself to evil to beat evil. It is natural that people who are in a suppressive situation tend to distort themselves and pursue radical solutions. It is very significant that they recognize the truth of the past, but knowing that sticking to the past shackles themselves and obstructs their development[20]. Maycon is obsessed with possessions, and Guitar is obsessed with violence to heal the loss of the past. Morrison points out that white's contempt for blacks cannot be the reason to deny or demean the identity of black existence, and the action of revenge like killing himself or the opponent cannot be justified[21].

Thirdly, the solution from Morrison is through Pilot. Pilot is an African American, a woman, a widow from the poor class, and she is the one who faces a lot of pressure from the discrimination of race, gender and class. She has no navel and she is isolated from the black community. Pilot is the one who is on the outskirts of the black community, but she does not think of revenge thinking of the oppression and scar she had. Rather, Pilot tries hard to live her life with happiness and thankfulness. Morrison explains that Pilot is a woman who has a deep affection for human relations, giving up the formal and inessential factors in life[22]. Pilot has true sympathy for humans, and she practices forgiveness and love in life which are the key to human relationships.

Pilot in Song of Solomon plays an important role as a healer consoling all the ones around her. Pilot helps Maycon and Luth restore their relationship by using the therapy of herbs, and Luth conceives Milkman. The image of Pilot as a therapist reminds us of Jesus who had pity on the poor and the weak based onthe Bible. Pilot and her brother Maycon have lived in a cave since their father was killed by a white. Maycon kills the white man and runs away. Pilot keeps the cinerary urn of the dead white at home and takes responsibility for her brother's sin. Pilot's attitude is in contrast to Milkman's ignorance on Hagar's love and Maycon's murder of a white. Pilot keeps reminding of the love of Jesus Christ on the cross by paying for the sins of others, not his own[23]. Pilot gives love, does not get angry or take revenge, even to the ones who betrayed her. Pilot's attitude is deeply related with the verses from 1 to 4 in thechapter 2 in Romans.

You, therefore, have no excuse, you who pass judgement on someone else, for at whatever point you judge the other, you are condemning yourself, because you who pass judgment do the same things. Now we know that God's judgment against those who do such things is based on truth. So when you, a mere man, pass judgment on them and yet do the same things, do you think you will escape God's judgment? Or do you show contempt for the riches of his kindness, tolerance and patience, not realizing that God's kindness leads you toward repentance?[24].

Pilot's nephew, Milkman and his friend, Guitar think the cinerary urn must be full of gold and sneak into her house to rob it. When they are captured by the police, Pilot visits there and absorbs all the ignorances from the white police to save them. Likewise, Pilot does not seek revenge against the ones who hurt to her. She is rather willing to advocate for them sacrificing herself. This way of Pilot's love for others can be linked with the action of Jesus in the verses from 5 to 10 in the chapter 5 of Romans in the Bible.

And hope does not disappoint us, because God has poured out his love into our hearts by the Holy 
Spirit, whom he has given us. You see, at just the right time, when we were still powerless, Christ died for the ungodly. Very rarely will anyone die for the righteous man, though for a good man someone might possibly dare to die. But God demonstrates his own love for us in this: While we were still sinners, Christ died for us. Since we have now been justified by his blood, how much more shall we be saved from God's wrath through him! For it, when we were God's enemies, we were reconciled to him through the death of his Son, how much more, having been reconciled, shall we be saved through his life! Not only is this so, but we also rejoice in God through our Lord Jesus Christ, through whom we have now received reconciliation[25].

Pilot counters evil with goodness. Unlike Maycon's hatred against whites taking away his family and their property, Pilot preserves the white's cinerary urn in the sack. Pilot does not have any anger or hatred to her cold brother Maycon, cynical Milkman and the discriminatory whites. She is only interested in loving others without any boundary. Pilot's love to others is distinguished from Seven Days reversely discriminating whites[26]. Her love is not restrictive and exclusive, but equal and allinclusive. She respects all lives regardless of race and loves all the sinners and strangers like Jesus's love for the world.

The love Morrison pursues in this novel is true love Jesus Christ put into practice in the Bible including genuine forgiveness and acceptance. Morrison compares black's love to the image of the young lamb in the Bible.Morrison suggests a way of healing black's scars through Pilot's life and death who gives endless mercy and love even to the ones who betrayed her. In Song of Solomon, the secret key of Milkman's desperate earning of flight is through truelove. In his childhood, Milkman loses his interest in life when he realized the fact that men could not fly. Milkman recognizes the secret of Pilot's flight and freedom through her death, and it is limitless and unbiased love. Milkman finally flies through true awakening of life with the love of Pilot.

There are different views on Milkman's flight. Some critics say that Milkman's flight shows the limit of irresponsibility in spite of his advance and flight in life.

Flight has a different meaning in it; it is a renumciation of others. Flight is both a victory and a danger paradoxically - a tragedy and a victory at the same time[27].

Others say that it is the symbol of black's spiritual longing for freedom. Milkman's flight is the act of selfishness, but it simultaneously is the act of love and the revenge for Pilot. Milkmans' flight is derived from love, and it is the act of heralding the message of resurrection in the verses from 1 to 5 in the chapter 6 in Romans of the Bible.

What shall we say, then? Shall we go on sinning so that grace may increase? By no means! We die to sin; how can we live in it any longer? Or don't you know that all of us who were baptized into Christ Jesus were baptized into his death? We were therefore buried in order that, just as Christ was raised from the dead through the glory of the Father, we too may live a new life. If we have been united with him like this in his death, we will certainly also be united with him in his resurrection[28].

The action of Milkman's flight can be understood as an irresponsible action ignoring Pilot's begging for him to take care of Liva. It is more rational translation of Milkman's decision for flight that Milkman lets his friend, Guitar feel real love and fly for freedom. Morrison mentions about Milkman's last flight in the interview with Bill Moyers as follows.

Milkman in the last part of Song of Solomon is overwhelmed and very strong and courageous. He is filled with love and ready for death. He was already ready for it, and to die or not is meaningless[29]. 
Milkman has full affection and love for Guitar. Milkman throws himself out to convey his awakening of the secret of flight to Guitar. Milkman approaches to the enemy who tried to kill himself with true love realizing through Pilot as Jesus's disciples approached to the Jews to evangelize. With the open ending of this novel, Morrison suggests the possibility of hope that the secret of free flight in life will be handed down to black descendents.

According to Therese E. Higgins's study of African legends, Pilot and Milkman are the figures who cannot fly[30]. First, they are not native Africans. Second, they are dyed in white society. However, Morrison says that the legend on flying African's myth is prophecy and the flight of Solomon is the prophecy of Milkman's flight. Milkman in Song of Solomon can get the power for flight by letting himself be in the air and an enemy like Pilot does for Milkman. The secret of flight for the descendents of Solomon that Morrison suggests is sacrificing and having humanitarian love shown in the Bible.

The consequential text of love compared inSong of Solomon and the Bible proves that sacrificing love which sublimates black's anger to noble love is melted into the two texts[31]. As Morrison mentions, the suffering African Americans experienced and the scars African Americans tried to overcome since liberation from are overcome by adapting the characteristic of Christian love to reality. Song of Solomon suggests Pilot's life and Milkman's true flight as a way of healing for the history of African American agony. Likewise, this study aimed to examine the message of cosmopolitan love melted in black lives including Morrison's philosophy which has a similar category with the text of the Bible.

\section{Conclusion}

This study examined and analyzed thecorrelation of true love and Christianity through the intertextuality of the two texts, Song of Solomonand the Bible. Christianity and the Bible have become a part of black lives since they suffered from the violence of slavery. The Bible had a crucial influence on African American's literature for much as their lives. Therefore, this study tried to look into the intertextuality of the Bible and Song of Solomon by examining Pilot's sacrifice and true love and Milkman's growth and flight in the comparison of Jesus's love in the Bible. The pure and true love of Jesus can also be read in the chapters of the Bible.

This paper reached the conclusion that true love in Song of Solomon embraces the cosmopolitan love which the Bible emphasizes. The value of loving each other in Song of Solomon had the same characteristic and commonality of love as the Bible. As Higgins explained that these two texts have the base of love with the sound self ego and aim to accomplish cosmopolitan love through the calling and response tor each other. The wrong self-ego caused a self-loss and the sense of inferiority and isolation. True love balancing calling and response and sharing giving and taking provided people to establish a strong self-ego. It was the cornerstone where someone could start their real independent life.

This research examined the power of true love based on the philosophy of Christianity in the text of Song of Solomon. It reflected Milkman's change and growth and Pilot's sacrifice and deep love. The relationship of Milkman and Hagar was disproportionate and selfishness. Guitar's violent attitude in life harmed and ruined himself. Maycon could not be free from the state of being a mental slave even after he accumulated his weath. Pilot was the one who took the responsibility of her brother's sin and willingly diedead instead of Milkman. As Higgins argued the power of ture love of human beings, this paper couldprove that Pilot's cosmopolitan love like that of Jesus Christplayed a significant role in changing and awakening the existence of human beings. This gradual growth and change was proven through the symbolic character, Milkman.

Jusus Christ forgave the ones who betrayed him and they were redeemed, and Milkman was reborn and tried to save his collapsed friend's soul. Milkman died for his friend without any hesitation, and finally flew. Through the analysis of the inter-textuality of the Bible and Toni Morrison's Song of Solomon, this research found that Higgins's assertion of the correlation of true love and Christianity 
from the two texts was quite persuasive, in that the little but concrete changes of characters toward true love in Song of Solomon had very close historical relations with true Christianityin the Bible. The reenlightenment of true love through this study will let blacks in American society achieve their right to live the horizontal and equal life that is deserved as human beings.

\section{References}

[1] Jeffrey C. Alexander, Ron Eyerman, Bernhard Giesen, Neil J. Smelser, Piotr Sztompka, Cultural Trauma and Collective Identity, University of California Press, (2004)

[2] Justine Baillie, Toni Morrison and Literary Tradition, Bloomsbury, (2013)

[3] Beth Benedrix, Intimate Fatality: Song of Solomon and the Journey Home, Tony Morrison and The Bible. Ed. Shirley A. Stave, New York: Peter Lang, (2006), pp.68-79.

[4] Victoria Burrows, Whiteness and Trauma, Palgrave Macmillan, (2014)

[5] Elliot Butler-Evans, Race, Gender and Desire: Narrative Strategies in the Fiction of Toni Morrison, and Alice Walker, Temple University Press, (1999)

[6] Todd Vogel, Shelley Fisher Fishkin, Robert Levine, Dickson Bruce, P. Gabrielle Foreman, Herman Beavers, Peter Carafiol, Carla Peterson, Ashraf H. A. Rushdy, Theresa Goddu, Jeffrey Steele, Criticism and the Color Line: Desegregating American Literacy Studies. Ed. Henry B. Wonham, Rutgers University Press, (2006)

[7] Michael G. Cooke, Modern Black Novelists: A Collection of Critical Essays, Prentice-Hall, (1999)

[8] Cornel West. Race Matter, Random House, (1994)

[9] Christiana Davis, An Interview with Toni Morrison, Conversation with Toni Morrison, Ed. Danville Taylor-Guthrie, University Press of Mississippi, (1994), pp.223-233.

[10] Saechan Oh, Toni Morrison's Song of Solomon: Decontruction of Dominant Culture, English and American Culture, (2001)

[11] Sheldon George, Approaching the "Thing" of Slavery: A Lacanian Analysis of Toni Morrison's "Beloved", African American Review, (2012), Vol.45, No.1/2, pp.115-130, https://www.jstor.org/stable/23783440

[12] Carolyn C. Denard, Toni Morrison: Conversations, University Press of Mississippi, (2008)

[13] Tidey Ashley, Limping or Flying? Psychoanalysis, Afrocentrism, and Song of Solomon, College English,(2000), Vol.63, No.1, pp.48-70, DOI: https://doi.org/10.2307/379031

[14] Harris Trudier, Fiction and Folklore: The Novels of Toni Morrison, University of Tennessee Press, (1991)

[15] Therese E. Higgins, Religiosity, Cosmology, and Folklore: The African Influence in The Novels of Toni Morrison, Routledge, (2001)

[16] Jamo Kang, Toni Morriso's Song of Solomon: Milkman's moral growth and its limit, The Journal of English Language and Literature, (1995), Vol.41, No.1, pp.125-147.

[17] Kukjin Lee. Korean English Explanation Bible. New International Version, NIV Publising Committee, (2006)

[18] Li Stephanie, Toni Morrison: A Biography, Greenwood Press, (2010)

[19] David L. Middleton, Toni Morrison's Fiction: Contemporary Criticism, Garland, (2000)

[20] Moyers, Bill, A Conversation with Toni Morrison, Conversation with Toni Morrison. Ed. Danville Taylor-Guthrie, University Press of Mississippi, (2004), pp.260-270.

[21] Toni Morrison, Song of Solomon, Vintage, (2004) 
A Study on the Correlation of True Love and Christianity through the Examination of the Inter-Textuality of the Bible and Toni Morrison's Song of Solomon

[22] Toni Morrison, Sula, Vintage, (2004)

[23] Toni Morrison, The Bluest Eye, Vintage, (2007)

[24] Bernice A. Pescosolido, Jack K. Martin, Jane D. McLeod, Anne Rogers, Handbook of the Sociology of Health, Illness and Healing, Springer, (2011)

[25] Charles Ruas, Toni Morrison, Conversation with Toni Morrison, University Press of Mississippi, (1994), pp.93-117.

[27] Gurleen Grewal, Circles of Sorrow, Lines of Struggle: The Novels of Toni Morrison, Louisiana State University Press, (2000)

[26] Salmon Rushdie, An Interview with Toni Morrison, Toni Morrison: Conversations, University Press of Mississippi, (2008)

[28] Shirley A. Stave, Toni Morrison and The Bible, Peter Lang, (2006)

[29] Willett Herbert Lockwood, Basic truths: of the christian faith, The christian century company, (1903)

[30] Susan Watkin, Twentieth-Century Women Novelists: Feminist Theory into Practice, Red Globe Press, (2000)

[31] David Z. Wehner, To Live This Life Intensely and Well: The Rebirth of Milkman Dead in Toni Morrison's Song of Solomon, Toni Morrison and The Bible, Peter Lang, (2006), pp.70-92. 